\title{
The role of social media Instagram community to tourism promotion in Baubau City
}

\author{
Nur Taqwa Utami a,1,* \\ ${ }^{a}$ Communication Sciences Study Buton Muhammadiyah University, Jl. Betoambari, Lanto, Batupoar, Kota Bau-Bau, Sulawesi Tenggara 93724 \\ ${ }^{1}$ Nurtaqwa48@gmail.com \\ * corresponding author
}

Article history

Received 09-11-2021

Revised 10-11-2021

Accepted 11-11-2021

Keywords

Social Media

Instagram

Tourism Promotion

\begin{abstract}
The tourism potential of Baubau City tends not to be able to compete in terms of promotion with several other regions. The tourism policy carried out by the local government has not been able to make tourism the main asset of the City of Baubau. This study examines the role of community social media in the tourism promotion of Baubau City, particularly on Instagram social media accounts. The research is focused on Instagram accounts that have tourism content and searches for hashtags that have the most posts about tourist objects. The research method used is descriptive qualitative. Next, to check the validity of the data, what the researchers did was to make previous observations on various relevant Instagram accounts randomly. Then the data that has been obtained is confirmed, described, categorized which is the same view, which is different, and which one is specific from the data sources. Finally, the data were analyzed by researchers to produce conclusions. The analysis technique used by these researchers is the source and content triangulation analysis technique. The results showed that community accounts on Instagram were very helpful in providing promotion for tourism in Baubau City, besides that the popular hashtags used made it easy for the public to get information about content, location, and access to several tourism objects in Baubau City.
\end{abstract}

This is an open access article under the CC-BY-SA license.

\section{Introduction}

Tourism Before describing the tourism condition of Baubau City, this research needs to provide a brief explanation of the Baubau City profile. Is a city located in Southeast Sulawesi province, with a land area of $221.00 \mathrm{~km} 2$, sea area reaching $30 \mathrm{~km} 2$, is a potential area for the development of sea transportation facilities and infrastructure. Consisting of 8 (eight) sub-districts and 40 (forty) subdistricts, with a population of 261,454 people at the end of 2018. Regionally, Baubau City is located in a connecting area, which allows for a very fast trade and service exchange. This of course can affect the social, economic, cultural, and political views of the people (Pencarelli, 2020).

The city of Bau-Bau was the center of the traditional government of the Buton Sultanate. BauBau City has several tourist objects including historical-cultural tours, for example, the Wolio Fortress and Keraton Wolio Cultural Center, natural attractions such as Lakasa Cave, Ntiti Cave, Palagimata Hill, Wantiro Hill, Kolema Hill, Kalampa. Sulaa, Latoondu Cave, Kaisabu Cave, BauBau River, Wakonti Nature Reserve, Sampora Waterfall, Bungi Bathing Place, and Tirta Rimba. The marine tourism is Kolagana, Nirwana Beach, Lakeba Beach, Kokalukuna Beach, and Kamali Beach. Around Kamali beach, there is also a monument which is named the Dragon monument which has been made a symbol by the Bau-Bau City government (Zinaida, Sunarto, \& Sunuantari, 2020). 
Tourism is a very strategic sector and following the vision of the City of Bau-Bau as the "Gateway to Economy and Tourism in Southeast Sulawesi". Cultural traditions, historical relics, natural beauty both at sea and on land, and other supporting facilities are potentials that need to be developed and preserved so that they can provide a touch of tourist attraction both domestic and foreign (Jandevi \& Zareen, 2020).

It's just that this condition is not balanced with adequate data on the tourist attractions of Baubau City, which can be calculated through the number of tourist visits. According to BPS data for Baubau City, through 2016 data the number of hotel guests from 347 foreign tourists to 126 in 2017, and domestic tourists in 2016 from 103,600 to only 7,702 tourists in 2017. Meanwhile, in 2018 as published through sultra.antaranews .com only lists the number of tourists, only over 4000 visits. This certainly indicates many things, one of which is tourism promotion that has not been able to increase the number of tourists.

\section{Theorotocal Framework}

\section{a. Tourism based on social media}

The Tourism is an unlimited economic resource, it's just that in its use this field requires adaptation to the social conditions of society and technological developments. For regions, the tourism sector also has a causal relationship that is strong enough to mutually influence the economic growth of a region.

A sound tourism policy will continue to strive to ensure that visitors are served in a way that maximizes benefits for stakeholders while minimizing the negative effects, costs, and impacts associated with ensuring the achievement of goals (Eko Nugroho, 2019). However, the times have changed towards the logic of the Internet of Things (IoT).

Baubau is one of the cities on the island of Buton in a row of the Southeast Sulawesi islands. In the TripAdvisor.co.id profile, it states that the City of Baubau has tourism objects, sultanates like those in Yogyakarta, Solo, and Cirebon which are called the Sultanate of Buton. In addition to this tourist city, you can also find several tourist objects including Buton Palace Fortress, Nirwana Beach, Lakeba Beach, Kalampa, Palatiga Hill, Bau Bau Kali, Lakasa Cave, Ntiti Cave, Kaisabu Cave, Bungi Natural Baths, Samparano Waterfall, Water Tirta Rimba waterfall, Laguna Waterfall, Kokalukunadan Beach, and other charming tourist objects.

However, along with this potential, tourism in Baubau City tends not to be able to compete in terms of promotion with several other areas. The tourism policy carried out by the local government has not been able to make tourism the main asset of the City of Baubau, which is also known as a transit area or liaison with the ownership of ports and airports as a link between the western and eastern regions of the archipelago.

It's just that, in recent years. Several online observations were made as to the data of this study that the growth of community-based social media is quite significant. For example, this can be observed in the growth of digital products made by people and communities. For example, Baubau Buy and Sell (in the Facebook Group), Buton Youtuber (Youtube), Info Buton Raya (Instagram), and others are based on the promotion of community activities and creativity-based community businesses.

In terms of efficiency, through social media, the provision of tourism information, tourism promotion, tourism agendas will reduce costs for limited promotional operations, resources, and physical infrastructure (Viswanath, Ramanadhan, \& Kontos, 2007). With social media, it can be simply understood that tourism in an area can build a positive image that is interrelated with tourism promotion. In the language of the tourism industry, advertising as a medium of information for tourists aims to form a destination image. Then, (Campelo, Reynolds, Lindgreen, \& Beverland, 2018) state that the image of a tourist attraction plays a very important role in determining the success of a tourist attraction.

In this way, the role of the media as mediation will provide good tourism promotion capabilities by utilizing a window that enables us to see beyond what is around us (McQuail \& Windahl, 2015). 
Joshua Meyrowitz added 3 parables; media as a channel, media as language, media as the environment (Fadillah, 2019).

Through the description of the phenomenon above, this study examines the role of community social media in the promotion of tourism in the city of Baubau, especially on Instagram social media accounts. The research will be assisted by tracing hashtags. Where, that hashtag is an Instagram feature that is used to make it easier for Instagram users to find the desired image in the search column (Faradies, 2020). This information will greatly strengthen the tourism image of the City of Baubau. Thus, these social networks will be used as input for the formulation of public policies regarding tourism development in the City of Baubau.

\section{Method}

The research method used is descriptive qualitative. The reason the researcher uses this method is that the researcher tries to describe and obtain information about the phenomenon or event systematically as it is. As in the phenomenon of the use of social media Instagram by the community which is used as a means of promoting regional tourism potential (Sugiyono, 2017).

The research process is fully carried out through community-based social media searches on Instagram, where the content it delivers is related to tourism objects in Baubau City. To facilitate data search, this study also tries to use hashtags (\#) as keywords to find out and compile data related to hashtags used as a medium for disseminating tourism content.

Next, to check the validity of the data, what the researchers did was to make previous observations on various relevant Instagram accounts randomly. Then the data that has been obtained is confirmed, described, categorized which is the same view, which is different, and which one is specific from the data sources. Finally, the data were analyzed by researchers to produce conclusions. The analysis technique used by these researchers is the source and content triangulation analysis technique (Sarifudin et al., 2020).

\section{Results and Discussion}

\section{a. Baubau City Tourism on Social Media}

As globalization continues to bring changes with various modes of modernity, it will continue to challenge every system of people's lives, because globalization has touched all aspects of life. One of them is the interaction model of social media globalization, such as facilitating the flow of information into people's lives, it can create a lifestyle that is different from before.

Social media then becomes one of the dominant media in influencing public perceptions of something. On the other hand, social media has the power to help government policies and correct government policies. Previously, many ways use social media was easy, cost-effective, and effective in tourism marketing for an area, so this has made social media more attractive for communication facilities and used in promoting tourism, for example using promotions on $\mathrm{TV}$, advertisements, brochures, and exhibitions (Putri, 2020).

In a connected era like today, the community in Baubau City is also used to promote tourism. It's just that this process is conscious and unconscious. This can be observed with the content that is distributed into people's Instagram feeds, those who realize the power of social media in the promotion of posting photos with several other information, while those who don't realize it are just posting photos for their existence and hobbies.

In an account search, which was carried out through the Instagram feed, it was found that several accounts were seriously used as a media for promoting tourism in Baubau City. In addition to inserting information on the photos posted, Instagram also makes edits and touches of interesting graphic designs. Interest is seen in the number of public responses to every post made through this account.

This research then categorizes the Instagram account into 5 (five) Instagram accounts, which are: 
Table 1. Instagram Account Baubau City Tourism content

\begin{tabular}{|l|l|l|l|}
\hline Name Account & $\begin{array}{c}\text { Number } \\
\text { Follower } \\
\text { s }\end{array}$ & $\begin{array}{c}\text { Number } \\
\text { of posts }\end{array}$ & \multicolumn{1}{|c|}{ Content-Type } \\
\hline @infobutonraya & 25,600 & 1,554 & $\begin{array}{l}\text { Info at Buton region } \\
\text { Kingdom }\end{array}$ \\
\hline @beritabaubau & 7112 & 576 & $\begin{array}{l}\text { set of BaubauInformation } \\
\text { About }\end{array}$ \\
\hline @explorebaubau & 4,113 & 264 & $\begin{array}{l}\text { LecationTravel } \\
\text { Locations Popular Baubau } \\
\text { City and }\end{array}$ \\
\hline @like_buton & 2,939 & 660 & $\begin{array}{l}\text { Tourist Locations on Buton } \\
\text { Island of }\end{array}$ \\
\hline @_baubaukeren & 316 & 42 & $\begin{array}{l}\text { Photos of Baubau City } \\
\text { Location and Offer of } \\
\text { Private Trip Services }\end{array}$ \\
\hline
\end{tabular}

From some of the data distribution of the accounts above related to tourism content in the city of Baubau, data shows that the number of account followers and the number of followers has a fairly large difference. It can be concluded that content posts can reach more people and a larger public.

That way, tourism promotion using several media above is believed to be able to provide more information to more people. The use of social media can be said as social media and can also be used to express experiences through photos or videos in the form of comments as a form of interaction not only with family but also with other people (Radojevic, Nguyen, Bajec, \& Ferra, 2020). Also, social media posts like the way above can at least influence public perceptions. As with Instagram, which is relatively new and has a major impact on encouraging tourist mobility (Sloan, Quan-Haase, \& Laestadius, 2017).

Meanwhile, the observation in terms of the strength of hashtags (\#) makes it easier for people to find information that is connected through hashtags. From the search, there are many kinds of hashtags that can guide people to get the information they want. Included in the search for information related to tourism locations in the City of Baubau. Some of the hashtags that have the most number of posts and followers are as follows:

Table 2. Distribution Map of 5 (five) popular on Instagram

\begin{tabular}{|l|l|}
\hline \multicolumn{1}{|c|}{ hashtag hashtags (\#) } & Number of posts \\
\hline \#baubau & $293 \mathrm{k}$ \\
\hline \#baubaukeren & $27.1 \mathrm{k}$ \\
\hline \#kotabaubau & $12.2 \mathrm{k}$ \\
\hline \#baubauinfo & $1000+$ \\
\hline \#baubauhitz & $1000+$ The \\
\hline
\end{tabular}

The main point in using hashtags is that it makes it easier for information to be found in a search engine. Using certain hashtags can direct searchers to something easily in the same column. In searching for data related to this, it was found that \#baubau was the most used in posts reaching 293 thousand times, followed by \#baubaukeren for 271 thousand times, this shows that content searched through the keyword baubau will be directed at posts that reach one million posts. 


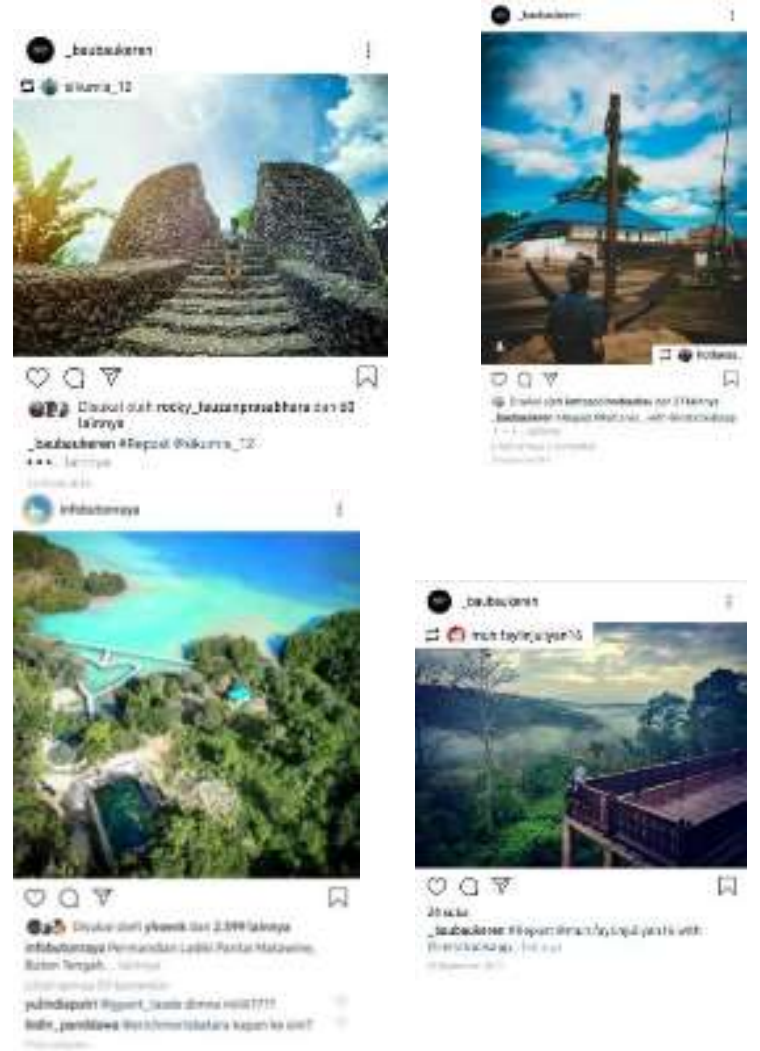

Fig. 1. Some poupular post about Tourism in the City of Baubau

Looking at this data later, it can provide an explanation that in addition to the use of an Instagram account that can become a tourism promotion media with wide coverage and low cost The use of hashtags is also considered able to provide convenience when people want to find content related to the desired keywords. This condition certainly provides benefits for local governments in disseminating tourism information, by utilizing community social media. This condition allows a tourism promotion policy that is cheap and has a broad reach.

In line with that, using social media for tourists or consumers can share their experiences and can also be used as a source in searching for information about tourist destinations. In addition to the large number of people who start ordering online to get tourism promotion, social media can also make the tourism industry more prosperous, creating business opportunities (Yeh, 2021).

Also, using tourism promotion through social media is considered cheaper (Mangold \& Faulds, 2009). It's just that there is still a need for innovation and a narrative that can provide information that is easy to understand and gives an impression to the public. Research from (Sánchez-Cobarro, Molina-Castillo, \& Alcazar-Caceres, 2021) shows how Instagram makes a destination for tourism brands in Indonesia, especially in Bali and Malang. Instagram is also useful in promoting gorobogan tours through posted image experiences (Kurniawati, Liana, Asharina, \& Permana, 2018).

\section{b. Social Media as an Effective Promotion Media}

In early 2020 a survey conducted by WeareSocial and Hootsuite revealed that internet users around the world have reached 4.5 billion people. This figure shows that internet users have reached more than 60 percent of the world's population or more than half of the world's population. From this data, it also turns out that 3.8 billion people have used social media. Facebook is still the most popular social media in the world with 2.449 billion accounts, followed by YouTube with 2 billion accounts and Instagram with 1 billion accounts. This certainly makes social media a space for the exchange of public information with a large number of interactions.

The main point of promotion on social media is the personal experience that users get. Like Instagram which has features that make it easy to find out the location of a tourist attraction. In their 
study, Fatanti \& Suyad provide a rule that user-based social media or User Generated Content (UGC) provides easy access for users to access information and also disseminates it to the public. Various interactions such as likes, comments, or even including hashtags as signs of certain objects. The "hospitality" of Instagram as a personal social media is still quite personal making it a favorite channel used by tour operators to promote tourist destinations (Harimudin, Fitriani, \& Sahar, 2020).

What happens in tourism promotion carried out in this study explains that, the community Instagram account and the use of hashtags in every post on a tourist attraction provide easy access for the wider community to access tourism information. It's just that, the social media currently in use is still community or managed independently, but there are no regional policies that can support the social media movement. Some of the identifications regarding this deficiency are that the use of information technology is still not optimal in regional policies.

On the other hand, the concept of a smart city that is being carried out by the local government of Baubau city is only limited to reforming the regional bureaucracy. This concept has not been decreased in service processes or policies that are providing services to the public by utilizing information technology. However, the existence of Baubau city tourism data that has been posted by the public and the community can compensate for the less than optimal tourism promotion policies carried out by the government.

One of the challenges in using social media as a tourism promotion channel is also in the concept of a Smart City. In Baubau, this concept continues to be improved in its implementation. A study that raises the potential for the development of the concept Smart City states that one of the opportunities that the City of Baubau needs to do in developing the smart city concept is a collaboration with the community (Sadat, 2019).

Several other studies claim that the Internet allows users to interact directly in several forms (Fadillah \& Jandevi, 2020). Unlike conventional advertising which is only unidirectional, social media allows users/consumers to ask questions, provide comments, input, or feedback. Examples of these forms of social media include blogs (WordPress), micro-blogs (Twitter), tourist behavior social networks (Facebook), photo/video media sharing sites (YouTube, Flickr), and Internet forums (Ong, H.Sutawijaya, \& Saluy, 2020). The point is that the success of a region's tourism promotion is not only determined by the active local government but also on the stretching of community entities in sharing and shaping regional tourism objects to netizens. That way, the development of the Internet Of Things (IoT) technology will make the role of local governments less due to the participation of the community.

Observing the above conditions, in several studies on social media, it is stated that interaction activities in social media are very important to increase the effectiveness of promotion, which in this case is tourism promotion (Cave \& Dredge, 2020). With the existence of social media, a reciprocal interaction is created. Meanwhile, there was a publication by Jupiter Research in 2009 that 50 percent of internet users consult their blogs before making a purchase. Then Nielsen's research also indicates that surprisingly, 81 percent of internet users see other people's opinions or reviews before going on vacation, 90 percent of internet users trust friends' recommendations, and only 14 of internet users trust advertisements.

\section{c. Conclusion}

However, this condition may differ from region to region depending on the policies of each region and the infrastructure of the region concerned. This can be observed in several regions in Indonesia, for example, Bandung, Bali, Banyuwangi, Jember, Solo, Purwakarta, Ambon, and Makassar. Tourism promotion is not only the duty of local governments but also content that is often disseminated by the community. As the City of Baubau, tourism potential is often the only potential without any room for affirmative policy movement in guarding the development and promotion of tourism. Even though the opportunity for digitization is currently growing rapidly by the community, the use of social media makes it possible to support tourism promotion policies in the regions. 
The times that have also led to regional policies in the realm of digitalization have made information technology a future policy direction that needs to be immediately responded to by the local government of Baubau City. Social media is one of them, which in this study explains that the use of social media as a means of promoting tourism provides several advantages, including social media that can provide personal experiences by users, provide easy search, the ability to find out the location of a tourist attraction. Meanwhile, the direct relationship with tourism promotion is that social media can reach a wider public, cheap, and opens up spaces for community participation and collaboration to support regional tourism promotion policies of Baubau City.

\section{Acknowledgment}

I am especially grateful for Mr. Arya and Mr. Fajar for their advice on this paper. and special thanks to lia my friends for her help and cooperation during my study.

\section{References}

Campelo, A., Reynolds, L., Lindgreen, A., \& Beverland, M. (2018). Cultural heritage. In Cultural Heritage. https://doi.org/10.4324/9781315107264

Cave, J., \& Dredge, D. (2020). Regenerative tourism needs diverse economic practices. Tourism Geographies, 22(3). https://doi.org/10.1080/14616688.2020.1768434

Eko Nugroho. (2019). Teoritisasi Komunikasi Dalam Tradisi Sosiokultural. Communicology: Jurnal Ilmu Komunikasi, 7(2), 236-253. https://doi.org/10.21009/communicology.012.09

Fadillah, D. (2019). SOCIAL MEDIA AND GENERAL ELECTION IN SOUTHEAST ASIA (MALAYSIA 2018 AND INDONESIA 2019). Jurnal Komunikasi: Ikatan Sarjana Komunikasi Indonesia, 4(1). https://doi.org/10.25008/jkiski.v4i1.255

Fadillah, D., \& Jandevi, U. (2020). Media-social behavior of Muhammadiyah members in China in the framework of Alexander Wendt's international communication constructivism. Journal of Social Studies (JSS), 16(1), 51-64. https://doi.org/10.21831/jss.v16i1.34604

Faradies, H. I. (2020). Strategi komunikasi city branding pemerintah kota Pekalongan dalam mempromosikan world's city of Batik. COMMICAST, $1(1), 20$. https://doi.org/10.12928/commicast.v1i1.2413

Harimudin, J., Fitriani, \& Sahar, S. (2020). Analisis Kesesuaian Lahan Untuk Pengembangan Kawasan Agrowisata di Kecamatan Sorawolio Kota Baubau. JAGAT (Jurnal Geografi Aplikasi Dan Teknologi), 4(1).

Jandevi, U., \& Zareen, M. (2020). Cross-cultural communication of the Indonesian students in China. International Journal of Communication and Society, 2(2), 79-85. https://doi.org/10.31763/ijcs.v2i2.96

Kurniawati, A., Liana, L., Asharina, N. P., \& Permana, I. (2018). Kajian Feminisme dalam Novel Cantik Itu Luka Karya Eka Kurniawan. Parole (Jurnal Pendidikan Bahasa Dan Sastra Indonesia).

Mangold, W. G., \& Faulds, D. J. (2009). Social media: The new hybrid element of the promotion mix. Business Horizons. https://doi.org/10.1016/j.bushor.2009.03.002

McQuail, D., \& Windahl, S. (2015). Communication models: For the study of mass communications, second edition. In Communication Models for the Study of Mass Communications, Second Edition. https://doi.org/10.4324/9781315846378

Ong, J. O., H.Sutawijaya, A., \& Saluy, A. B. (2020). Strategi Inovasi Model Bisnis Ritel Modern Di Era Industri 4.0. Jurnal Ilmiah Manajemen Bisnis, 6(02).

Pencarelli, T. (2020). The digital revolution in the travel and tourism industry. Information Technology and Tourism, 22(3). https://doi.org/10.1007/s40558-019-00160-3

Putri, R. D. (2020). Strategi komunikasi rumah kreatif sleman dalam upaya pengembangan UMKM di era ekonomi digital. COMMICAST, l(1), 14. https://doi.org/10.12928/commicast.v1i1.2412 
Radojevic, R., Nguyen, D., Bajec, J., \& Ferra, I. (2020). Visual framing and migrant discourses in social media: The story of idomeni on instagram. In Understanding Media and Society in the Age of Digitalisation. https://doi.org/10.1007/978-3-030-38577-4_8

Sadat, A. (2019). POLA KOMUNIKASI ANTAR PRIBADI MELALUI INTERNET DI KALANGAN REMAJA. MEDIALOG: Jurnal Ilmu Komunikasi, 1(1). https://doi.org/10.35326/medialog.v1i1.302

Sánchez-Cobarro, P. de H., Molina-Castillo, F. J., \& Alcazar-Caceres, C. (2021). The brand-generated content interaction of instagram stories and publications: A comparison between retailers and manufacturers. Journal of Theoretical and Applied Electronic Commerce Research, 16(3). https://doi.org/10.3390/jtaer16030031

Sarifudin, Evendi, H. H., Jumasa, M. A., Surjono, H. D., Hasana, S. N., Maharany, E. R., ... Samatowa, U. (2020). Metode Penelitian Kuantitatif, Kualitatif, dan R \& D. In JPM : Jurnal Pendidikan Matematika.

Sloan, L., Quan-Haase, A., \& Laestadius, L. (2017). Instagram. In The SAGE Handbook of Social Media Research Methods. https://doi.org/10.4135/9781473983847.n34

Sugiyono. (2017). Metode Kuantitatif dan Kualititatif. Jurnal Agribisnis Indonesia.

Viswanath, K., Ramanadhan, S., \& Kontos, E. Z. (2007). Mass media. In Macrosocial Determinants of Population Health. https://doi.org/10.1007/978-0-387-70812-6_13

Yeh, S. S. (2021). Tourism recovery strategy against COVID-19 pandemic. Tourism Recreation Research, 46(2). https://doi.org/10.1080/02508281.2020.1805933

Zinaida, R. S., Sunarto, S., \& Sunuantari, M. (2020). City branding of Palembang: understanding cultural identification through logo and tagline. International Journal of Communication and Society, 2(1), 30-40. https://doi.org/10.31763/ijcs.v2i1.106 